\title{
Test Repetition From The Viewpoint of Biological Variation
}

\author{
Hikmet Can Çubukçu' ${ }^{1}$ iD
}

${ }^{1}$ Ankara University Stem Cell Institute, Interdisciplinary Stem Cells and Regenerative Medicine, Ankara, Turkey

Hikmet Can ÇUBUKÇU

\section{ABSTRACT}

Purpose: The present study was set out to investigate the effect of test repetition within the biological variation perspective by addressing reanalyzing an individual sample on total variation. This study also demonstrated to what extent a laboratory result of an individual reflects a homeostatic set-point.

Methods: The total variation values were determined for different coefficients of analytical variation (CVA) corresponding optimum (CVA $=0.25 \times(\mathrm{VI})$, desirable ( $\mathrm{CVA}=0.5 \times \mathrm{CVI})$, and minimum ( $\mathrm{CVA}=0.75 \times \mathrm{CVI})$ limits of performance specifications for imprecision. The effect of a number of analytical measurements on the total variation for a single sample was simulated. Furthermore, the percentage of closeness to the true homeostatic setting point (D) was determined for commonly used 27 analytes.

Results: This study showed that the total variation reduction with reanalysis of an individual sample was lower than $19 \%, 10 \%$, and $3 \%$ for the tests meeting the minimum, desirable and optimum level of specification limits, respectively. Furthermore, the reduction was only $9.4 \%, 5.1 \%$, and $1.5 \%$ for duplicate analysis of an individual sample at the abovementioned limits.

Conclusion: This study demonstrated that test repetition has a negligible effect on the total variation, especially when analytical performance meets optimum and desirable performance specifications. D values reported in this study can guide laboratory professionals and clinicians about to what extent a result of an individual reflects homeostatic set-point.

Keywords: Clinical Laboratory Science, Intra-Individual Biological Variation, Quality Improvement

\section{Biyolojik Varyasyon Açısından Test Tekrarı}

ÖZET

Amaç: Bu çalışma, tek bir örneğin yeniden analiz edilmesini ele alarak biyolojik varyasyon perspektifinde test tekrarının toplam varyasyon üzerindeki etkisini araştırmak için düzenlenmiştir. Bu çalışma aynı zamanda bir bireyin laboratuvar sonucunun ne ölçüde bir homeostatik ayar noktasını yansıttığını da göstermiştir.

Yöntemler: İmpresizyon için performans spesifikasyonlarının optimum (CVA $=0.25 \times(\mathrm{VI})$, istenen (CVA $=0.5 \times \mathrm{CVI})$ ve minimum (CVA $=0.75 \times \mathrm{CVI}$ ) sınırlarına karşlık gelen farklı analitik varyasyon katsayıları (CVA) için toplam varyasyon değerleri belirlendi. Toplam varyasyona tek bir numunenin analitik ölçüm sayısının etkisi simüle edildi. Ayrıca, yaygın olarak kullanılan 27 analit için gerçek homeostatik ayar noktasına (D) yakınlık yüzdesi belirlendi.

Sonuçlar: Bu çalışma, tek bir numunenin yeniden analizi ile toplam varyasyondaki azalmanın, minimum, istenen ve optimum spesifikasyon limitlerini karşılayan testler için sırasıyla $\% 19, \% 10$ ve $\% 3$ 'ten düşük olduğunu göstermiştir. Ayrıca, yukarıda belirtilen limitlerde tek bir numunenin çift analizi için azalma sadece $\% 9,4, \% 5,1$ ve $\% 1,5$ olmuştur.

Sonuç: Bu çalışma, özellikle analitik performansın optimum ve istenen performans özelliklerini karşıladığı durumlarda, test tekrarının toplam varyasyon üzerinde inmal edilebilir bir etkiye sahip olduğunu göstermiştir. Bu çalışmada rapor edilen D değerleri, bir bireyin sonucunun homeostatik ayar noktasını ne ölçüde yansıttığı konusunda laboratuvar uzmanlarına ve klinisyenlere rehberlik edebilir.

Anahtar Kelimeler: Klinik Laboratuvar Bilimi, Birey Içi Biyolojik Varyasyon, Kalite lyileştirme

\section{Received : 14 November 2021 \\ Accepted $\quad$ : 2 December 2021}


V ariations determine to what extent a laboratory test result represents the real value of an analyte (1). Some sources of laboratory errors like the preparation of a patient, collection, transportation, and storage of samples constitute challenging but preventable causes of variations $(2,3)$.

Apart from the aforementioned pre-analytical issues, analytical variation and inherent biological variation constitute two critical components of variation (1). Analytical variation is assessed by some specification limits to keep it to be as good as needed to be fit for the purpose. One of the widely used specification limits is derived from the biological variation databases. Random analytical error, bias, and total error of clinical laboratories can easily be compared with these goals to ensure laboratories' compatibility (4). Random analytical error designated as imprecision defines the closeness of measured values obtained by repetitive measurements under specified conditions. Standard deviation and analytical coefficient of variation (CVA) are utilized to express imprecision (1). Furthermore, the analytical coefficient of variation gains various areas of usage in the clinical laboratory as calculating reference change value (RCV) (5) and measurement uncertainty (MU).

Daily, monthly and seasonal changes occur in the levels of some analytes of an individual. In addition to these changes, there is inherent random fluctuation around the instantaneous homeostatic setpoint, called within-subject biological variation (6).

A practical formula suggested previously is utilized to determine total short-term variation by taking into consideration the analytical variation and within-subject biological variation (1):

$C V_{T}=\sqrt{ }\left(C V_{A}^{2} / n_{1}+C V_{1}^{2} / n_{2}\right)($ Formula I)

$\mathrm{CV}_{\mathrm{T}}$ : total variation

$\mathrm{CV}_{\mathrm{A}}$ : analytical variation

$\mathrm{CV}_{1}$ : within-subject biological variation

$\mathrm{n}_{1}$ : total number of analytical measurements

$\mathrm{n}_{2}$ : number of samples taken from the individual
Test repetition, including reanalyzing an individual sample and resampling, can be considered when an erroneous result is suspected. These two approaches can be regarded within the biological variation perspective. The present study was set out to investigate the effect of test repetition within the biological variation perspective by addressing reanalyzing an individual sample on total variation. This study also demonstrated to what extent a laboratory result of an individual reflects a homeostatic set-point.

\section{MATERIAL AND METHODS}

The total variation values were determined for different CVAs corresponding optimum (CVA $=0.25 \times \mathrm{CVI})$, desirable $(C V A=0.5 \times C V I)$, and minimum $(C V A=0.75 \times C V I)$ limits of performance specifications for imprecision according to Formula I (1) given below:

$\mathrm{CV}_{\mathrm{T}}=\sqrt{ }\left(\mathrm{CV}_{\mathrm{A}}^{2} / \mathrm{n}_{1}+\mathrm{CV}_{1}^{2} / \mathrm{n}_{2}\right)$

$\mathrm{CV}_{\mathrm{T}}$ : total variation

$\mathrm{CV}_{\mathrm{A}}$ : analytical variation

$\mathrm{CV}_{1}$ : within-subject biological variation

$\mathrm{n}_{1}$ : total number of analytical measurements

$\mathrm{n}_{2}$ : number of samples taken from the individual

The effect of a number of analytical measurements ( $n 1$ ) on the total variation for a single sample $(\mathrm{n} 2=1)$ was simulated using Formula I.

The number of samples ( $\mathrm{n}$ ) needed to get defined closeness (D) to the true homeostatic setting point assuming single analysis were calculated for 27 analytes including, alanine aminotransferase (ALT), aspartate aminotransferase (AST), gamma-glutamyl transferase (GGT), alkaline phosphatase (ALP), lactate dehydrogenase (LDH), creatinine kinase (CK), amylase (AMY), pancreatic amylase (PAMY), lipase (LIP), sodium (Na), potassium (K), chloride $(\mathrm{Cl})$, magnesium $(\mathrm{Mg})$, inorganic phosphorus (IP), total cholesterol, high-density lipoprotein cholesterol (HDL-C), low-density lipoprotein cholesterol (LDL), non-highdensity lipoprotein cholesterol (non-HDL), triglycerides, glucose, urea, uric acid, total protein, total bilirubin, direct bilirubin, and hemoglobin A1c ( $\mathrm{HbA} 1 \mathrm{c})$ using the following Formula II (1): 
$\mathrm{n}=\left(\mathrm{Z} \times \sqrt{[}\left[\mathrm{CV}_{\mathrm{A}}^{2}+\mathrm{CV}_{1}^{2}\right] / \mathrm{D}\right)^{2}$

$\mathrm{CV}_{\mathrm{A}}$ and $\mathrm{CV}_{\mathrm{I}}$ : as in formula I

D: The percentage of closeness to the true homeostatic setting point.

Z: Coverage factor set to 1.96 corresponding to a $5 \%$ false rejection rate

The Formula II was inversely modified to yield D as a function of $\mathrm{n}$ in the Formula III:

$D=\left(1.96 \times \sqrt{ }\left[C V_{A}^{2}+C V_{1}^{2}\right]\right) / \sqrt{ } n$

The number 1.96 is the above-mentioned Z-score.

When there is no test repetition with an additional sample, $n$ equals 1 .

The percentage of closeness to the true homeostatic setting point (D) was determined for 27 analytes mentioned above.

Micorsoft Excel version 16.54 was used for reanalysis simulation.

\section{RESULTS}

Figure 1 shows simulation outcomes related to the effect of reanalyzing an individual sample on total variation. Reanalyzing an individual sample reduced the contribution of analytical variation to the total variation and eventually decreased overall total variation. The reduction in the total variation reached a steady-state level by the increasing number of reanalysis.

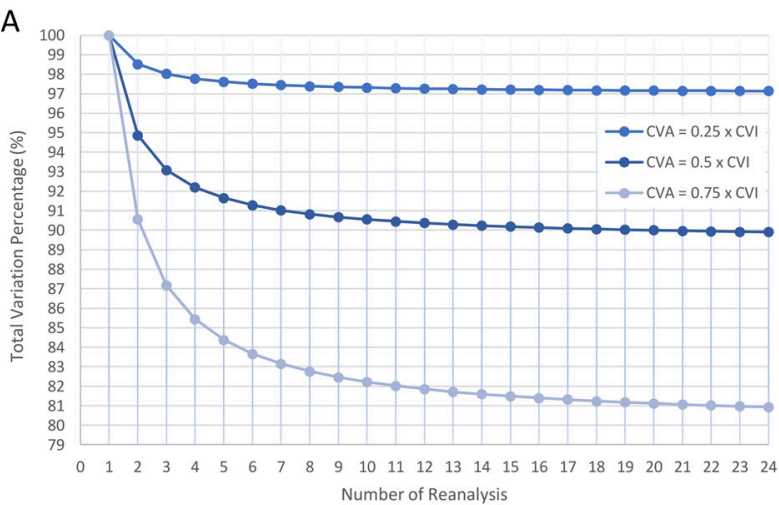

The variation reduction was $\sim 3 \%$ for $C V A=0.25 \times C V I, \sim 10$ $\%$ for CVA $=0.5 \times \mathrm{CVI}$, and $\sim 19 \%$ for CVA $=0.75 \times \mathrm{CVI}$ at steady-state levels.

The number of samples needed to get defined closeness (D) to the true homeostatic setting point is given for 27 analytes in Table 1. While one sample is sufficient to achieve $10 \%$ closeness to the homeostatic setting point for $\mathrm{Na}$, $\mathrm{K}, \mathrm{Cl}, \mathrm{Ca}, \mathrm{Mg}$, IP, total cholesterol, glucose, total protein, $\mathrm{ALP}, \mathrm{LDH}$, and $\mathrm{Hba} 1 \mathrm{C}$, other analytes require more than one sample to achieve $10 \%$ closeness. An analytical measurement of a sample results in different $D$ values for each analyte. Interestingly, the D value is over $40 \%$ for triglycerides, total, and direct bilirubin tests for a single measurement of a single sample (Table 1).

\section{DISCUSSION}

The effect of reanalysis on total variation was mainly dependent on imprecision. The reduction in the variation was lower for lower CVA (Figure 1). The true value of a measurand should be within "the analysis result $\pm D^{\prime}$ " when pre-analytical variation is reduced to an insignificant level. The present study deduced D values for 27 analytes.

The effects of test repetition on total variation were investigated in two studies. Firstly, Peterson showed that repeating tests with high individuality indexes can decrease false-positive test results (7). Then, Fraser elucidated this issue by proposing the aforementioned useful formula (Formula I). This formula has shown that reanalyzing an individual sample and resampling decrease contributions of analytical variation and intraindividual biological variation (1).

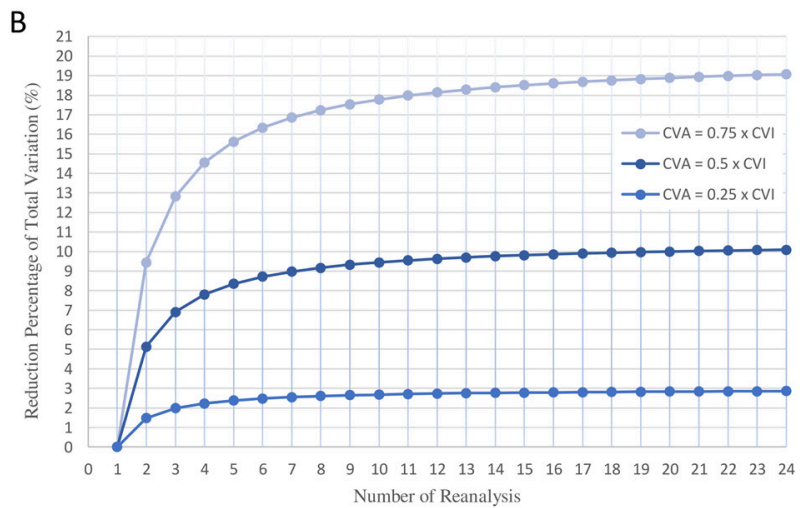

Figure 1: Relationship between number of reanalysis and total variation for different thresholds of CVA, A: The change of total variation with increasing number of reanalysis, B: Reduction percentage of total variation with increasing number of reanalysis. 
A desirable analytical variation should be lower than half of the within-subject biological variation (4). When the test performance complies with these specification limits, the contribution of analytical variation to total variation will be significantly lower than within-subject biological variation (1). In the same way, the present study showed that the total variation reduction with reanalysis of an individual sample was lower than 19\%, 10\%, and 3\% for the tests meeting the minimum, desirable and optimum level of specification limits, respectively (Figure 1). Furthermore, the reduction was only $9.4 \%, 5.1 \%$, and $1.5 \%$ for duplicate analysis of an individual sample at the abovementioned limits. These findings have shown that reanalyzing an individual sample does not substantially reduce the total variation, especially for the tests meeting desirable and optimum specification limits.
In terms of resampling, Formula II could be considered (1) for calculating the number of samples ( $n$ ) needed to get defined closeness (D) to the true homeostatic set-point assuming a single analysis conducted. Fraser questioned resampling numbers proposed by some guidelines in 2004 (1). However, biological variation data have been updated since 2004. Moreover, within-subject biological variation values were reduced to some degree. Therefore, $\mathrm{n}$ has also been reduced. A novel example of the number of samples to reach $10 \%$ closeness to the true homeostatic set-point by using biological variation data (8-10), has been given in Table 1. It was postulated that test CVAs were at the desirable specification limits. This study showed that only one sample with a single analysis is sufficient for $\mathrm{Na}, \mathrm{K}, \mathrm{Cl}, \mathrm{Ca}, \mathrm{Mg}$, IP, total cholesterol, glucose, total protein, ALP, LDH, and Hba1c to reach $10 \%$ closeness to the true homeostatic set-point (Table 1).

\begin{tabular}{|c|c|c|c|c|}
\hline Analytes & $\% \mathrm{Cv}_{1}$ & $\%$ Desirable Imprecision & $n(D=10 \%)$ & $\% D(n=1)$ \\
\hline ALT & 9.3 & 4.7 & 4 & 20.4 \\
\hline AST & 9.5 & 4.8 & 4 & 20.8 \\
\hline GGT & 8.9 & 4.5 & 4 & 19.5 \\
\hline ALP & 5.3 & 2.7 & 1 & 11.6 \\
\hline $\mathrm{LDH}$ & 5.2 & 2.6 & 1 & 11.4 \\
\hline CK & 14.5 & 7.3 & 10 & 31.8 \\
\hline AMY & 6.8 & 3.4 & 2 & 14.9 \\
\hline PAMY & 6.3 & 3.2 & 2 & 13.8 \\
\hline LIP & 7.7 & 3.9 & 3 & 16.9 \\
\hline $\mathrm{Na}$ & 0.53 & 0.3 & 1 & 1.2 \\
\hline $\mathrm{K}$ & 3.92 & 2.0 & 1 & 8.6 \\
\hline $\mathrm{Cl}$ & 0.98 & 0.5 & 1 & 2.2 \\
\hline $\mathrm{Ca}$ & 1.81 & 0.9 & 1 & 3.9 \\
\hline $\mathrm{Mg}$ & 2.88 & 1.4 & 1 & 6.3 \\
\hline IP & 7.67 & 3.8 & 3 & 16.8 \\
\hline Total Cholesterol & 5.18 & 2.6 & 1 & 11.4 \\
\hline $\mathrm{HDL}$ & 5.67 & 2.8 & 2 & 12.4 \\
\hline LDL & 8.46 & 4.2 & 3 & 18.5 \\
\hline non-HDL & 6.88 & 3.4 & 2 & 15.1 \\
\hline Triglycerides & 19.8 & 9.9 & 19 & 43.4 \\
\hline Glucose & 4.7 & 2.4 & 1 & 10.3 \\
\hline Urea & 14.1 & 7.1 & 10 & 30.9 \\
\hline Uric acid & 8.32 & 4.2 & 3 & 18.2 \\
\hline Total protein & 2.6 & 1.3 & 1 & 5.7 \\
\hline Total bilirubin & 20.9 & 10.5 & 21 & 45.8 \\
\hline Direct bilirubin & 20.9 & 10.5 & 21 & 45.8 \\
\hline Hba1c & 1.2 & 0.6 & 1 & 2.6 \\
\hline
\end{tabular}


Inversely, Formula II was used to yield $\mathrm{D}$ as a function of $\mathrm{n}$ in the novel Formula III. Formula III can be used to interpret results near reference interval limits. The true value of a measurand should be within "the analysis result $\pm D^{\prime \prime}$ (for only one sample, the formula III becomes $1.96 \times \sqrt{ }\left(\mathrm{CV}_{\mathrm{A}}^{2}+\right.$ $\left(V_{1}^{2}\right)$ ) when pre-analytical variation is reduced to an insignificant level. Therefore, if a result $\pm D$ involves a reference limit, test repetition with an additional sample may change analyte level status. On the other hand, if the analysis result $\pm D$ does not include a reference limit, test repetition will not change analyte level status when there is no laboratory error. The laboratorians and clinicians should regard the aforementioned "grey zones" in this aspect.

The percentage of closeness (\%D) to the true homeostatic set-point of a result achieved by only one sample with a single analysis is given in Table 1. This table can guide laboratorians and clinicians about to what extent a result of an individual reflects homeostatic set-point.

The present study is limited by representing the calculations ( $D$ and $n$ values) reflecting the homeostatic set-point in only healthy individuals. Biological variation data can be affected by health status. Therefore, the $n$ and $D$ values should be interpreted with this caution.

\section{CONCLUSION}

This study demonstrated that test repetition has a negligible effect on the total variation, especially when analytical performance meets optimum and desirable performance specifications. Therefore, reanalyzing an individual sample should preferably be performed in case of analytical error and resampling when a pre-analytical error exists.
Authors' Contributions

Hikmet Can ÇUBUKÇU conducted this study and wrote the article.

\section{REFERENCES}

1. Fraser CG. Test result variation and the quality of evidence-based clinical guidelines. Clinica chimica acta; international journal of clinical chemistry. 2004;346:19-24. DOI:10.1016/j.cccn.2003.12.032

2. Simundic AM and Lippi G. Preanalytical phase--a continuous challenge for laboratory professionals. Biochemia medica. 2012;22:145-9.

3. Ricós C, Perich C, Minchinela J, et al. Application of biological variation-a review. Biochemia medica. 2009;19:250-9.

4. Ricos C, Alvarez V, Cava F, et al. Current databases on biological variation: pros, cons and progress. Scandinavian journal of clinical and laboratory investigation. 1999;59:491-500.

5. Fraser CG. Reference change values. Clinical chemistry and laboratory medicine. 2011;50:807-12. DOI:10.1515/cclm.2011.733

6. Fraser CG. Biological variation: from principles to practice: Amer. Assoc. for Clinical Chemistry; 2001.

7. Petersen PH, Sandberg S, Fraser CG, et al. Influence of index of individuality on false positives in repeated sampling from healthy individuals. Clinical chemistry and laboratory medicine. 2001;39:160-5. DOI:10.1515/cclm.2001.027

8. Carobene A, Roraas T, Solvik UO, et al. Biological Variation Estimates Obtained from 91 Healthy Study Participants for 9 Enzymes in Serum. Clinical chemistry. 2017;63:1141-50. DOI:10.1373/ clinchem.2016.269811

9. Aarsand AK, Diaz-Garzon J, Fernandez-Calle P, et al. The EuBIVAS: Within- and Between-Subject Biological Variation Data for Electrolytes, Lipids, Urea, Uric Acid, Total Protein, Total Bilirubin, Direct Bilirubin, and Glucose. Clinical chemistry. 2018;64:1380-93. DOI:10.1373/clinchem.2018.288415

10. Carlsen S, Petersen PH, Skeie $\mathrm{S}$, et al. Within-subject biological variation of glucose and $\mathrm{HbA}(1 \mathrm{c})$ in healthy persons and in type 1 diabetes patients. Clinical chemistry and laboratory medicine. 2011;49:1501-7. DOI:10.1515/cclm.2011.233

\title{
DECLARATIONS
}

Funding

The present study was not funded by any corporation

\section{Conflicts of Interest}

The author declares no conflict of interest.

\author{
Ethics Approval \\ Not applicable.
}

Availability of Data and Material

Not applicable. 